\title{
Urban geographies of refugee journeys: biopolitics, neoliberalism and contestation over public space in Belgrade
}

Political Geography, accepted for publication 31 August 2018.

Jelena Obradovic-Wochnik

Senior Lecturer in Politics and International Relations

Aston University, Birmingham

j.obradovic-wochnik@aston.ac.uk

\section{Introduction}

In January 2017, as temperatures reached -20 degrees in Serbia, the United Nations High Commissioner for Refugees reported that around 1000 refugees were living in abandoned warehouses in central Belgrade (UNHCR 2017a). This derelict settlement (known as 'The Barracks') has since been evicted and demolished, because it was located on a piece of land earmarked for a new, luxury development of hotels and apartments - the $£ 2.8 \mathrm{bn}$ 'Belgrade Waterfront', funded by an Emirati Investment firm and the Serbian government. The squat, occupied by refugees and attended to by ad hoc networks of volunteers and activists, forms a part of the 'constellation of camps' (Davies et al 2015:93) and informal settlements (Tsavdaroglou 2018; Mudu and Chatopadhyay 2017; Depraetere and Oosterlynck 2017) emerging across Europe. Informal settlements, where refugees experience 'violent abandonment' of host states (Davies et al 2015:93). Settlements existing outside of formal refugee camps have become an integral part of refugee journeys, but also form a focal point for host states' surveillance and regulatory practices directed at refugees. Whereas formal camps in transit countries act as 'stations' and 'stop over points' on migratory routes to Western and Northern Europe (Tsianos and Karakayali 2010:384), but they produce rationalities and effects which have a direct bearing on the refugees' presence in (or removal from) urban areas, as this paper discusses.

This paper examines the urban and spatial politics of refugee journeys through transit countries; specifically, it considers the relationship between urban spaces adapted and used by refugees and solidarity activists, and the biopolitical rationalities of neoliberalism, the state and the EU border regimes. I argue that, for transit states along migratory routes, refugees in urban and public spaces play two converging roles: first, they are seen as bodies occupying commercial areas and second, they are subjects of migration and asylum policies, and as such are subjected to constant intervention, scrutiny, counting and management. I argue that the refugees' dual roles, as 'disruptors' of commercial development and migratory subjects, mean that state authorities are keen to not only push them away from public spaces, but also push them towards camps, for which national governments of transit countries receive EU 
funding. This differentiates refugee populations from other marginalised groups, such as the homeless: there are no comparable spaces designated for other urban 'undesirables' especially none which are funded by external/international actors. This is especially the case in migratory transit countries such as in South Eastern Europe, where the under-developed welfare sectors have poor provision for homelessness and other types of social marginalisation, but where conversely, refugee accommodation is relatively well funded by external actors such as the EU.

Using Belgrade as a case study, I show how the state's commercial interests in the city centre property development became intertwined with its implementation of asylum policies requiring all refugees to reside in official, state-run camps, subsequently resulting in constant surveillance, conduct and regulation of refugee bodies in urban areas. The surveillance and regulation of refugee bodies are, in turn, carried out by a constellation of actors at state, city and municipal levels, and includes property developers, business owners, local residents, migration workers and the police. The constellation of actors often engages in seemingly banal practices restricting the use of public space, such as evictions, putting up fences, and demolitions of informal settlements, which are intended to encourage refugees to register themselves for residence in official camps. Refugees in urban areas are attended to by networks of aid organisations, volunteers and activists, who often frame their work as resistance against state and/or EU border regimes, but whose work sometimes unwittingly supports the rationalities of government through the focus on counting refugees or working with state authorities. Against this background, I highlight the importance of understanding local politics and pre-existing contestations over space, and their entanglement in the 'flexibility' of modern borders (Medzzara and Neilson 2012:65)

The paper builds on literature which suggests that geography and space, particularly harsh and inhospitable physical environments, feature in border control strategies, but also in their subversion (Doty 2011; Mountz 2013; Rygiel 2011; Davies et al 2017; Johnson 2016; Squire 2015). For refugees, cities can become 'biopolitical spaces [...] where migrant lives are held hostage', but also spaces where the biopolitical regime can be challenged (Topak 2014: 830; Doty 2011). In Belgrade, refugees and aid groups challenged the urban order by finding new and innovative ways of making their physical environments more 'survivable' (c.f. Johnson 2015). The authorities continually deployed the urban environment against refugees and activists through surveillance, evictions or demolitions (often coinciding with ongoing construction of the Belgrade Waterfront), but also by actively pushing refugees towards official camps.

Using the framework of biopolitics - the management of life and bodies (Foucault 2000) the paper reflects on rationalities of capitalism, development and urban regeneration, which have spatial effects on lives and movement across cities, as well as borders. I use the 
biopolitical framework in order to reveal the 'subtle wielding of contemporary power' (Doty 2010). Biopolitics of urban environments - implicit and explicit rules about who can use public spaces and when, rationalities of neoliberalism and regeneration, surveillance of space and contestations over land use - have a direct impact on the emergence of informal camps and zones of exclusion (Rygiel 2011), and hence shape the lives and everyday struggles of refugees and their aid providers. Host countries often 'regulate the presence of refugees in urban areas' to prevent integration and reduce their agency (Fabos and Kibreab 2007:5), and generally prefer asylum seekers and refugees to reside in official camps (Johnson 2016). As Sanyal notes (2012:637-639), the presence of refugees in the city complicates the strategy of containment pursued by most governments, and hence refugees' presence in cities is often clandestine, criminalised or seen as a 'hindrance to urban development', which the Belgrade case illustrates.

A rich literature documents the increasing interest of refugees living in cities, which now make up half of the world's refugee population (Sanyal 2012:633; Maestri and Hughes 2017). Many of the discussions around urban refugees focus on how claims to citizenship and belonging are made in urban spaces (Maestri and Hughes 2017; Bauder 2016; Nyers 2010; McNevin 2006). Recent work also explores the use of urban spaces to stage protests, build solidarity and resist violence of border regimes (Depraerte; Nordling et al 2017; Johnson 2016), and examines the extent to which refugee squats in constitute a 'radical autonomy' (Mudu and Chattopadhyay 2017). For instance, writing about the Maximillian park in Brussels, Depraetere and Oosterlynck (2017:705) note that the park 'became a site for acts of citizenship' where volunteers became 'political actors by taking up responsibility for incoming refugees.' However, as Nordling et al (2017) argue, such spaces are ambiguous. They are 'not spaces for clear cut political activism or insurgency, but neither are they spaces only of care, hospitality or compassion' as they can 'become political....in unpredictable ways' (Nyers 2017:731). Thus, informal spaces or spaces of solidarity cannot be seen only in terms of 'resistance' to border regimes or authorities (a position activists often adopt): informal 'resistance' based aid groups sometimes become a part of the state's own apparatus for accommodating refugees once they start working formally in camps for instance (as is the case with a number of Belgrade-based NGOs). Some activist groups also adopt more pragmatic positions and cooperate with authorities, whilst other aid groups find that they have to rely on state- or city- level authorities and services (such as police and social work) in order to meet the needs of specific groups of refugees, such as unaccompanied minors.

Emergent literature also considers the 'commons' arising out of informal refugee settlements and cooperatives in places like Athens, and considering cooperative housing in terms of articulation of rights, identities and collectivities (Tsavdaroglou 2018). As Tsavdaroglou (2018:19) explains, this discussion builds on existing literature on urban 
solidarity and social movements 'which have the ability to destabilise state-led policies' and upset 'dominant taxonomies of urban spaces'. However, as I argue, considering informal refugee settlements in urban centres also necessitates an analysis of how they are affected not just by the state, but also by neoliberalisaton, financial capital, property development and local politics in which they are embedded.

I build on the existing literature which considers the presence of refugees in cities, but I also extend the discussion by suggesting that refugees' and activists ability to use, adapt and make spaces political or sites of citizenship, is circumscribed by the existence of official refugee camps (towards which authorities actively push refugees), rules, regulations and biopolitics of urban environments and neoliberalism which inevitably manage and restrict access to seemingly 'free' public spaces (Bulley 2016). I do this by taking a closer look at the relationships between urban space, financial capital and state power and the effects they produce.

Belgrade is used as a case study to illustrate the convergences of migration and neoliberalisation. The city is an especially rich case study showing what happens when refugees become a part of local debates about state-led property redevelopment, whilst also being the subjects of a well-funded EU assistance programme that has increased the number of refugee camps in the country. To date, the EU has provided financial assistance to Serbia worth EUR 80 million, for 'better border management, running costs of the centres [refugee camps] and also for improving reception conditions and provisions of services in the education and the health sector. ${ }^{1}$ The presence of EU funds has created spaces towards which refugees could 'legitimately' be conducted towards once they were evicted from urban areas.

Belgrade also embodies urban transformations typical of post-socialist cities, where appropriations of public space are marked continuities 'of dominant state power [...], neoliberal economy, everyday corruption and haphazard attempts by civil society to [...] inscribe its own signs into the cityscape' (Darieva and Kaschuba 2011:14). As a case study, it sheds a light on the effects of rapid neoliberalisation and 'wild capitalism' with 'rapacious rent-seeking', absence and/or a disregard for state regulation, semi-legal business activity, an informal economy (Upchurch and Marinkovic 2018) and a distribution of capital based on clientism (Harloe 2011). It shows clearly the spatial effects of a rapid transition (Sykora and Bouzarovski 2011), which include construction booms and privatisation of formerly state-owned properties (see e.g. Pugh 2005), but also informal or illegal construction in public spaces (Vojovic and Petrovic 2007; Hirt 2008). This also means that Belgrade allows us to observe the rapid disappearance and 'monetarization' of public spaces, which often takes places with the aid of state authorities or individuals in office (Pugh 2005:448). In turn, we can observe that in 'transition' countries, neoliberalisation often involves a principal actor (c.f. Hirt 2013:30) - the 
state - which also happens to play the same central role in other core functions, such as migration policy, and we can thus observe how migration and neoliberalism intersect.

This paper is structured as follows. I first outline the methodology. Then, the following section defines the key concepts used in the paper, and engages in a discussion of biopolitics and neoliberalism. The next section provides a short background to the refugee crisis in Serbia, noting in particular its spatial effects. The subsequent section describes spaces and spatial practices employed by activists and authorities, explored through descriptions of key spaces: public parks, squats and aid centres in Belgrade. Each discussion of a specific site charts how public spaces used by refugees and activists transformed, over time, into Waterfront sites, and the rationalities this has produced.

\section{Methodology}

This paper is based on extensive qualitative data gathered over the course of six trips to Belgrade, between November 2015 and June $2018^{2}$. The total amount of time spent in the city over the course of these trips was nine weeks. The aim was to understand, 'from below', the effects of urban transformation, evictions and demolitions linked to the Waterfront development, on refugee communities and their supporters. To this end, I collected forty-six interviews and around sixty informal conversations, which participants consented to being used but did not want to have recorded. The interviews and conversations were with: staff from the major aid organisations and NGOs working with refugees in Serbia (some organisations, such as Refugee Aid Serbia and Medicines Sans Frontieres were interviewed multiple times), smaller local aid organisations such as Info Park NGO, smaller international and volunteer-led organisations such as the BelgraAid NGO; a major international donor agency; officials from the Serbian Commissariat for Refugees, a state agency responsible for housing and looking after refugees; staff managing an official refugee reception centre on the outskirts of Belgrade; European activists from the No Border movement, local volunteers and activists, social workers, interpreters, local researchers, academics, squatters and refugees. When citing interviewees, I specify whether the interviewee is an 'aid worker' (working for an NGO or larger organisation), a volunteer, or an activist (a label some interviewees chose to describe themselves).

I employed ethnographic research methods throughout: for instance, I shadowed and observed the No Border activists in their work, and participated in a squat clean-up they had organised. I observed the work and interactions of other activists and aid workers. For instance, over multiple visits, I observed the day-to-day work of volunteers, social workers and interpreters at three volunteer-run refugee support centres. During the course of my 
observations of activist groups in particular, I was granted access to the refugee squats, where I was able to observe at first hand their living conditions. Throughout my extensive observations of the local parks, the aid centres, squats and other focal points, I was also able to sketch out more extensive pictures about how these spaces are used and navigated by various groups, and I draw on those observations in this paper. Whilst immersive and based on participant observation, this project is not extensive enough to be 'an ethnography' and I make no claims as such; I merely note that the methods employed drew on ethnographic practices such as participant observation.

The majority of the interviews I carried out were with volunteers and activists, and I am aware of the potential ways in which this may skew the interpretation of data, and it does indeed place the emphasis on their experience of the state and the state's role in regulating public spaces. Further, despite wishing to interview refugees and include their stories in this paper, the language barriers made in-depth interviews and discussions difficult (though, we did manage a number of conversations). Therefore, I make no claims about this data being representative in any way; the limitations mean that the data shows my interpretation of how the informal settlements were used and how they were affected by the Waterfront development and local authorities.

\section{Cities, neoliberalism and biopolitics}

Migration scholars have theorised how physical spaces might be used as migration 'deterrents' and tools to counter resistance movements' solidarity efforts (Doty 2011; Johnson 2015; Squire 2014). Physical environments such as deserts, Doty (2011:607) suggests, are so harsh and have a 'raw physicality', that they can be 'put to use and function to mask the workings of social and political power'. Reflecting on the US border policy, Doty (2011:607) argues that deaths of migrants trying to reach the US through the desert, can be blamed - by the authorities - on harsh weather conditions and 'natural causes', thus allowing them to evade responsibility. Whilst cities are not comparable to deserts, Doty's point is echoed by scholars who suggest that urban environments are continuously and intentionally made inhospitable and unsurvivable for groups (such as the homeless for instance) who are not deemed to be a 'legitimate' part of the public (Fraser 1990; Mitchell 1995; Davis 1990; Bulley 2016).

What cities look like, how public spaces are to be used, and what can and cannot be done, built or demolished in the urban environment are the results of local and/or global practices, rules and regulations constructed and maintained by authorities, institutions, capital, agents and individual actors - what Foucault conceptualised as biopolitics or the technologies of power (Foucault 1997: 246). Foucault saw biopolitics as interventions into and management of life, which also included 'control over relations between the human race....and their 
environment, the milieu in which they live' (Foucault 1997:245). Foucault notes further that biopolitics 'deals with the population [...] as a political problem [...] a biological problem and as power's problem' (Foucault 1997:246).

Foucault saw biopolitics as operating through 'territorial controls and surveillance, practices of death and exclusion and the suspension of rights' (Topak 2014:830). Urban environments show how this works on a smaller scale. In cities, biopolitical processes, Kraftl (2014:275275) argues, can be 'constituted through architectural practices', including design, planning and inhabitation; that is, urban design is deployed for purposes of biopolitical control, often visible, as Kraftl (2014) shows, in the ways in which housing estates are structured to shape their inhabitants lives in specific ways. This resonates with work of urban theorists and geographers who suggest that space in cities is governed such that bodies move through urban environments in particular ways (Bulley 2016). Discussing spatial governing of cities Bulley (2016:244) distinguishes the surveillance of a space - whereby a space is closed and bordered - and the regulation of a space, which takes place through more liberal forms of conduct, such as regulation of flows of people and goods through open spaces. Further, Bulley (2016: 245-246) suggests that circulation around cities is not completely free, because we are 'conducted into certain areas' and away from others, often through 'mundane, everyday tactics' such as transport links or licensing laws, and movements such as Occupy, attempt to disrupt the cities' attempt at regulation of these flows. Seemingly mundane practices contribute to what Foucault saw as 'the actual production of self-governed life within modern spaces' (Sparke 2006:157), and adaptation of individual behaviours in line with expected norms.

In cities, regulatory practices and conduct of people through physical spaces are also shaped by neoliberalism and commercial activity as well as shadow economies, such as people smuggling. Here, I adopt a broad (though not uncontested) definition of neoliberalism as an ideology 'organised around the twin ideas of liberalising the capitalist market from state control and refashioning state practices in the idealised image of the free market' (Sparke 2006:153-154). Peck et al (2011) argue that neoliberalism can more accurately be described as a process of 'neoliberalisation'. In post-socialist contexts, this has seen governments implement neoliberal economic policies characterised by deregulation, roll back of the state and its intervention, and privatisation of state-owned enterprises and services (Jessop 2002:454). Neoliberalism in various 'transition' contexts has thus 'become the dominant ideological rationalization for globalization and contemporary state "reform"' (Brenner and Theodore 2009:94).

Importantly, as Sparke (2006:154-157) argues, despite emphasis on 'deregulation', 'neoliberalism leads in practice to re-regulation' in ways that can be observed if we examine the 'messy actualities' and the 'nitty gritty activities of biopolitical production' of specific neoliberal projects. For instance, Springer (2010:1033) notes that neoliberalism can be seen 
as a form of Foucauldian governmentality, and as 'an assemblage of rationalities, strategies, technologies, and techniques' that allow for 'governance at a distance' (Barry et al. 1996 in Springer 2010:1033). One effect resulting from this assemblage and its self-disciplining of subjects, is that neoliberalism privileges 'individuals who conform to the norms of the market' whilst those who do not, such as the homeless, are 'managed' and disciplined through security regimes of surveillance, policing and border controls (Springer 2010:1033).

Viewed from the vantage point of cities, it is possible to observe the 'nitty gritty activities of biopolitical production' (Sparke 2006:154-157) and the ways in which they derive both from neoliberalisation and border control. Refugees, like other urban 'undesirables' are assumed not conform to the capitalist logic outlined by Springer (2010). In reality, they often do have access to financial capital but their ability to access sites of commerce is regulated both explicitly and implicitly, by authorities policing the 'porous borders' (Tsianos and Karakayali 2010:374) in cities, or business owners preventing access to shops and services, for instance. The rest of the paper examines biopolitical effects of the convergence of neoliberalism and border control on populations that not only 'deviate' from the idealised neoliberal-citizen subject (Sparke 2006; Springer 2010).

\section{Background}

\section{Waterfront Development}

The story of the refugee crisis in Serbia is one which repeatedly converges with another story - that of the investor-led urban regeneration scheme known as 'Belgrade Waterfront'. The Waterfront project embodies the kind of re-regulation of neoliberalism described by Sparke (2006:157) in that it shows how, on the one hand, foreign investors could take advantage of local deregulation but at the same time, rely on the state to minimise their investment risk (c.f. Grubber and Camprag 2018).

The Waterfront is a large-scale and multi-use project redeveloping 1.77 square kilometres of brownfield sites in downtown Belgrade; a run-down, river-side neighbourhood called Savamala. The city's railway and bus stations are located here, and in 2015 become focal points of the refugee crisis. The Savamala neighbourhood had experienced a post-socialist 'boom in bottom up spatial interventions' (Cvetinovic et al 2016:16) as groups and individuals developed derelict and abandoned buildings (whose post-socialist ownership was not always clear) into bars, clubs and arts centres, some of which later became refugee aid distributions points. Waterfront plans includes demolishing much of Savamala and rebuilding the area from scratch. This includes moving the central bus and railway stations and demolishing an entire area of socialist-era cargo yards and workers' housing (which later became refugee squats, 
as discussed below).

There are few publicly available facts about the project apart from the marketing material and press releases, since information has been systematically withheld from the public by the State Commission for Protection of Competition and at the request of the investor (Grubbauer and Camprag 2018:14).

The Serbian government is the key partner in the project with an Abu Dhabi-based property developer, Eagle Hills, as the only other investor. The project would see the Serbian state 'lease 100,000 acres of land to Eagle Hills, to build 200 objects' and 'the investor would enjoy extra territorial rights over 30 years' (Matkovic and Ivkovic 2017:6). Eagle Hills develops luxury properties, and Waterfront is its only project in Europe ${ }^{3}$. The project is symptomatic of postfinancial crisis capitalism in which global financial capital becomes 'anchored' into the built environment (Halbert and Rouanet 2013) and investors from the Middle East seek to diversify their income through property development in what would have traditionally been seen as high risk markets (Grubber and Camprag 2018). Importantly, as Grubber and Camprag (2018:913) discuss, it is the national government and not local authorities, that have a key role in this type of regulatory capitalism as they constantly change the law and regulation, and sidestep local government and experts in order to reduce the risk for investors and ensure project implementation.

Waterfront will consist of 6000 luxury apartments, shopping malls, offices for 12,000 workers, and eight hotels. Whilst some public areas such as the riverside 'promenade' and a playground are also included, the development has been widely criticised for not building affordable housing or adequate public spaces, for being a 'state-driven' model of 'hypergentrification' with an 'absolutely consumerist vision' (Eror 2105) and 'an extreme case of speculative real estate development driven by the priorities of rent extraction' (Grubbauer and Camprag 2018:12). As such, Belgrade Waterfront is an example numerous 'urban mega projects' globally that have been criticised on grounds of transparency, lack of benefit to the public and accusations of corruption (Mihailovic 2014; Grubbauer and Camprag 2018:1-3). Further criticism is levelled at the opaque financing of the project, and it is suspected that Serbian state and taxpayers, not investors, are bearing much of the financial liability (Greenberg and Spasic 2017:323). The Waterfront development is just one of many instances of contemporary neoliberal projects, concerned with 'voicing the interests of financial and/or transnational capital' (Jessop 2002:455), and which allow us to see how cities become key sites through which neoliberalism is reproduced (Peck et al 2009:50). The logic of capitalism embodied by Waterfront, which prioritised investment capital, had spatial effects which managed and conducted refugee bodies away from specific sites. 
Construction of the Waterfront development started in earnest around the same time that large numbers of refugees reached Belgrade in 2015. Serbia, whose hosting of refugees is embedded in broader European border policies, became one of the focal points of the Balkan Route following the 'opening' of the Greece-Macedonia border in 2015, which enabled refugees to move northwards, heading for EU borders in Hungary and Croatia (Afouxenidis et al 2017:16). However, the subsequent 'closure' of Hungarian and Croatian borders from autumn 2015 trapped the refugees in Serbia and Greece. The border itself is not sealed, and following Tsianis and Karakayali's calls to move away from the image of a 'Fortress Europe' (2010), it is important to note that movement (mainly facilitated by smugglers) across South East European borders still occurs. However, the Western Balkans' 'strongmen' leaders have become 'indispensable partners managing the EU's refugee crisis', with the EU itself 'struggling' to create a unified approach (Pomorska and Noutcheva 2017:170; see also Beznec et al 2017).

Serbia's approach to asylum is consistent with other countries in the region, in that there is an underlying assumption that most refugees reaching the Balkans are not intending to settle there (Afouxenidis et al 2017). However, most EU funding appears to be supporting the long-term stay of refugees in transit countries. EU funding is comprehensive, and supports everything from the additional social workers and interpreters, to improving accommodation in camps. EU's policies have a spatial effect too: refugees cannot access any support services unless they are registered as residing in official reception centres, and all of the funding that the state receives is based around camps and support services working with camp populations. It also means that the Serbian government places a strong emphasis on camps, and has an incentive to remove urban refugee populations into camps.

Serbia's 'reception' or 'asylum' centres are in effect, refugee camps though the use of this term is avoided by migration officials ${ }^{4}$. Centres/camps allow for a relative freedom of movement. However, many of the camps are isolated, and not served by public transport. The camp-containment strategy has not changed, and throughout 2016 and 2017, new camps were opened to increase capacity to a total of 17 across the country. All camps provide shelter, meals and healthcare, though their quality and frequency is varied. This reflects problems across Europe, particularly Greece, where camp conditions vary dramatically between locations and with some island camps labelled as 'total chaos' (Lamb 2016:710), whilst other camps are shown to international visitors as examples of successful refugee accommodation ${ }^{5}$. In a further similarity to Greece, refugees in Serbia sometimes reject camps due to their isolation, lack of opportunities for work, integration and mobility (Tsavdaroglou 2018). Refugees also report being unable to access camps in Serbia and being turned away by camp 
officials for various reasons such as 'incorrect' paperwork or overcrowding in 2016 when flows of people were high $^{6}$, though this seems to be less of a case at present.

Since 2015, some groups of refugees in Serbia have been using public spaces - parks, garages, derelict buildings - to live, sleep and wait for transport or smugglers. Again, this reflects the situation elsewhere in Europe: refugees arriving into Athens in 2015, for instance, started to settle in the city's central public park, Pedion Areos until accommodation was available elsewhere (Afouxenidis et al 2017:30). Central urban areas became focal points primarily due to their proximity transport hubs by which many arrived and left. But, refugees' use of centrally located urban areas is in part also influenced by smugglers. Smugglers not only transport refugees into urban areas, but also choose the locations in which refugees will be dropped off, thus unwittingly shaping the geographies of refugee presence in cities. In Belgrade, the drop offs continue to be on or in the vicinity of land acquired by the Waterfront Project ${ }^{7}$ as discussed below.

\section{Surveillance and regulation of public places and refugee presence}

Public spaces such as squares and parks featured prominently in the refugee 'crisis', mainly as places of protest, solidarity and the delivery of aid (Depraetere and Osterlynck 2017; Johnson 2016; Afouxenidis et al 2017). However, public spaces are subject to various explicit and implicit rules, regulations and surveillance practices aimed at preventing specific groups of people - traditionally, the homeless; more recently, the refugees - from using central, public or commercial sites (Fraser 1990; Mitchell 1995; Davis 1990; Bulley 2016). This 'control through the management of space' as Merry argues, is a form of spatial regulation that often involves the production of social order by concealing specific populations and behaviours, rather than eliminating them. This, and the temporal nature of spatial regulation where concealment occurs at specific times and not others (Merry 2001:17) is evident in the way that the Serbian authorities tolerated the presence of refugees in public spaces during the height of the media attention in 2015 , which very quickly shifted to 'concealment' as the Waterfront construction got under way later that autumn. The following section reflects on concealment, surveillance and regulation by taking a detailed look at four key spaces that started out as refugee solidarity sites, but ended up becoming a part of /adjacent to the Waterfront development.

\section{The Park/Park View Apartments}

When refugees arrived into Belgrade, they found themselves either at the central bus 
station or one of the parks immediately adjacent to it. According to several plans of the Waterfront site, the two public parks appear incorporated into the new development ${ }^{8}$. However, no other information has been provided on this in any public statement by the government so my assessment is based solely on the maps provided by developers on the Waterfront website. The parks are also one street away from the showpiece 'Belgrade Waterfront Sales Centre', one of the first buildings to be completed as a part of the project; on the same street, activists had set up a refugee aid distribution site in 2015 , but as discussed below, this turned out to have been on a tranche of land acquired for the development.

In the summer of 2015 , the two parks became the sites of first informal settlements, as people slept in tents. At the time of writing, they are fenced off with Waterfront Billboards advertising 'Park View Apartments', refugees and activists having been displaced over a period of two years. In the early days of the refugees' arrival into Serbia, the parks became physical sites which helped provide basic means of survival but also constitute a refugee community and solidarity networks. The sites were adapted to include a Red Cross medical clinic, meal distribution points, an 'Info Park' information hut, legal aid and meeting points for Arabic and Farsi-speaking volunteers. Exact numbers of people living temporarily in the parks are unknown, however, activists estimate them to be in the thousands in the summer of 2015, to a few dozen in $2017^{9}$. Visibility and presence of refugees in a busy, central space was important in mobilising local support. The presence of refugees in public spaces also aided accessibility, allowing volunteers and agencies to establish contact and provide aid without government regulation.

The local authorities' approach to removal of refugees from public spaces is framed by the broader rationality of the refugee camp, and the EU financing which supports the Serbian refugee camp system. Thus, whilst refugees face similar restrictions on the use of public spaces to other marginalised groups, they are also subjected to rationalities of (EU) border security and its financing of refugee camps. This means that refugees are subjected to different biopolitical and financial rationalities than other marginalised groups, such as constant surveillance, interventions and counting.

EU funding has created new spaces (reception centres), towards which refugees are conducted by the state from 2015 onwards. Until the arrival of EU funds into Serbia, the country had a small number of refugee reception centres whose conditions were often poor. Many of the centres also housed Croatian Serb refugees from the 1990s, and as two of my interviewees commented, the conditions in which Croatian refugees lived were poor and the spaces neglected ${ }^{10}$. With the arrival of new refugees, the camp subsequently received various streams of international and EU funding for refurbishment and services (including food, maintenance and security). The existence of new and improved reception centres thus allows the state to adopt an openly interventionist narrative, in which officials often state that the best 
place for refugees is the camp, with its numerous services, food provision and security ${ }^{11}$. No such narrative is adopted for other marginalised populations - drug users, homeless, sex workers, the Roma - because no comparable spaces or policies exist for them locally. Subsequently, EU policies and funding dedicated to supporting refugees in Serbia, have also created hierarchies of marginalised populations, in which the non-refugee marginalised continue to be neglected by the state, whilst the 'new' arrivals receive funding, spaces and care because they are explicitly linked to the EU's currently priorities and border security agenda.

EU's funding to Serbia is contingent on refugee bodies being present in camps - refugees cannot access services unless they are registered as camp residents - and this produces rationalities, such as counting and surveillance, to which refugees are subjected but other marginalised groups are not. Camps themselves receive funding which is calculated per person residing there ${ }^{12}$. Camps also carry out a daily roll call of refugees, with updated daily lists sent to local police stations ${ }^{13}$ and the Commissariat for Refugees also publishes data on numbers of refugee camp residents ${ }^{14}$. Refugees are also counted by aid organisations and volunteers who keep figures updates in order to know how many meals to prepare each day, for instance. Conversely, Serbia has no official statistics for the homeless population, for instance (Sarajlija et al 2014:167).

Against this background, local authorities were engaged in a slow and subtle process of surveillance and monitoring of both refugees and activists using the parks. Both refugees and solidarity activists using public spaces attracted the attention of local authorities in a way that other marginalised populations have not. Whilst Serbia has a rich tradition of public protest (see e.g. Jansen 2001), they have rarely coalesced around marginalised populations using those same public spaces. The visible presence of largely international and European volunteer-activists publicising the refugees' plight, threatened Serbia's official narratives of being a refugee-friendly country (see e.g. Naskovic 2017; this view was supported by interviews I conducted with Serbian Commissariat for Refugees staff in June 2018).

It has been argued that the use of public spaces by refugees and their allies is an act of politics or re-appropriation of public spaces from which they are normally excluded (Johnson 2016:958). This is certainly the case with many activist groups such as No Borders who consciously and explicitly frame their activities as political and resisting EU border regimes. For instance, throughout 2016, solidarity activists helped refugees assert their presence in the park (c.f. Johnson 2015) and occupy spaces by living there, participating in daily food distribution, organising sports activities, taking up space by e.g. distributing maps, information and refugees' artwork on trees and later on, organising protests against the governments' asylum laws. These activities helped constitute the parks as solidarity spaces and transformed the material environment (Pink 2008:166); in a way that other local marginalised groups are 
unable to do. As such, other marginalised groups such as the homeless or the Roma are not as 'threatening' to the local authorities whose approach towards them is often marked by indifference.

Refugees and their solidarity support groups used the physical space in much more visible and disruptive way than other marginalised groups who do not have as many vocal and international allies, and their activity often took place in spaces on or near Waterfront sites. For instance, not only were the parks visibly marked by refugee presence with large Red Cross containers, tents, information huts, food stalls, photographs, graffiti and people themselves but the parks were also 'renamed' by refugees and activists. One was 'Afghan Park' (the parks also bore graffiti inscriptions such as 'Afgh', names of individuals, and phone numbers of people on the move). Another nearby park was informally renamed into 'Kurdish Park' in 2017, after large numbers of Kurdish refugees started arriving and using this space to wait for smugglers ${ }^{15}$. 'Afghan Park' and 'Kurdish Park' are a few blocks away from each other, linked by a long street which later came to house two drop-in day centres for refugees. The area itself had been renamed 'Refugee District' by the refugees and smugglers ${ }^{16}$.

However, it should perhaps be emphasised that it is the activist groups themselves that framed their activities in terms of resistance - for most refugees, and other aid groups like MSF or Info Park, the provision of aid in public spaces is seen mainly in terms of basic survival and immediate care. Nevertheless, the existence of robust voluntary aid networks allowed the government to concentrate its efforts on trying to conduct people towards camps and 'conceal' (c.f. Merry 2001) refugees away from public areas, rather than providing aid (outside of camps) themselves. Spatial regulation, as Merry (2001) argues is always temporal, and the Belgrade case shows that the local authorities intensified their efforts of conducing refugees towards camps just as EU borders 'closed' and Waterfront construction picked up pace. Some months after the parks were cleared (discussed further below) the park closest to the bus station was partly closed off with a construction fence advertising the Waterfront 'Park View' apartments.

Biopolitical control was not only exercised upon the refugee population once they were living in the parks, rather, they were already subjects of a biopolitical and regulatory regime prior to their arrival. The biopolitics of the camp - the attempts to create self-regulating subjects who would deliver themselves to the camp without coercion - is precisely what led to parks becoming informal settlements. Some refugees 'chose', specifically, not to enter the camp and to subject themselves to further regulatory practices which limited mobility, created routines and cut refugees off from smugglers and aid providers.

Whilst the local authorities never made the link between refugee presence and the Waterfront development explicit, they did engage in a series of evictions, surveillance activities and demolitions in and around the Waterfront site, around the time that Waterfront construction began, and with direct effect on the refugee population. The presence of state authorities was 
not always felt directly - whilst there was some police presence in the parks, and surveillance of the refugee population increased, it never reached the levels of policing seen in other places such as Hungary (especially along the border). The Belgrade case demonstrates 'governance at a distance' (Barry et al 1996; Springer 2010): the state and its institutions (border enforcement or national police) were often invisible, with regulatory power diffused to various actors, some of whom are not normally involved in migration nor policing - demolition crews, or park maintenance, for instance. It demonstrates what Ferguson and Gupta (2002:984) called the 'less dramatic, multiple, mundane domains of bureaucratic practice by which states reproduce spatial riders and scalar hierarchies'.

Whilst biopolitical control and surveillance of refugees and migrants tends to be concentrated along border zones (Topak 2014:830), it is also evident in seemingly innocuous, everyday spaces that do not immediately seem to have a relevance to migration policies. In Belgrade, surveillance and biopolitical control of the parks increased over 2015 and 2016, and eventually pushed most of the refugees out of the parks. However, surveillance was predominantly carried out by local authorities including the Belgrade 'communal' (municipal) police, a subdivision of the Serbian police force concerned primarily with enforcement of rules and regulations that fall within the jurisdiction of the city such as noise disturbance; and the Commissariat for Refugees, a bureaucratic government department whose workers patrol the parks on a daily basis, but have no law enforcement powers.

Throughout 2016, No Border activists started to report increasingly intrusive questioning by the police and Commissariat staff, who confronted them in the parks ${ }^{17}$. One activist reports verbal harassment ${ }^{18}$. Simultaneously, refugees began reporting that they often found park surfaces soaking in water (having been 'cleaned' by the street cleaning teams) which prevented them from sleeping there, and repeated incidents of police officers disrupting individuals by shining torches into their tents at night.

One key practice that allowed local authorities to enhance their surveillance and security performances, was the construction of a large orange fences that bisected the parks and made them virtually impossible to use. The plastic orange fences were built in July 2016 by park maintenance teams. Activists claim that they were told that new grass was being planted behind fenced areas. They saw this as an unsubtle attempt to restrict their use of the park. The immediate effect the fence had was to cut off most of the park from use, recalling Mitchell's (1995) points on the subtle management of public spaces and Bulley's (2016) observation that cities continually conduct flows of people in and out of specific areas. The fence made it more difficult for refugees to sleep in the park, and for aid to be provided. The fence is thus one instance of how state's 'institutional power was being spatialised' in order to limit refugees' mobility (Davies and Isakjee 2015:94). 


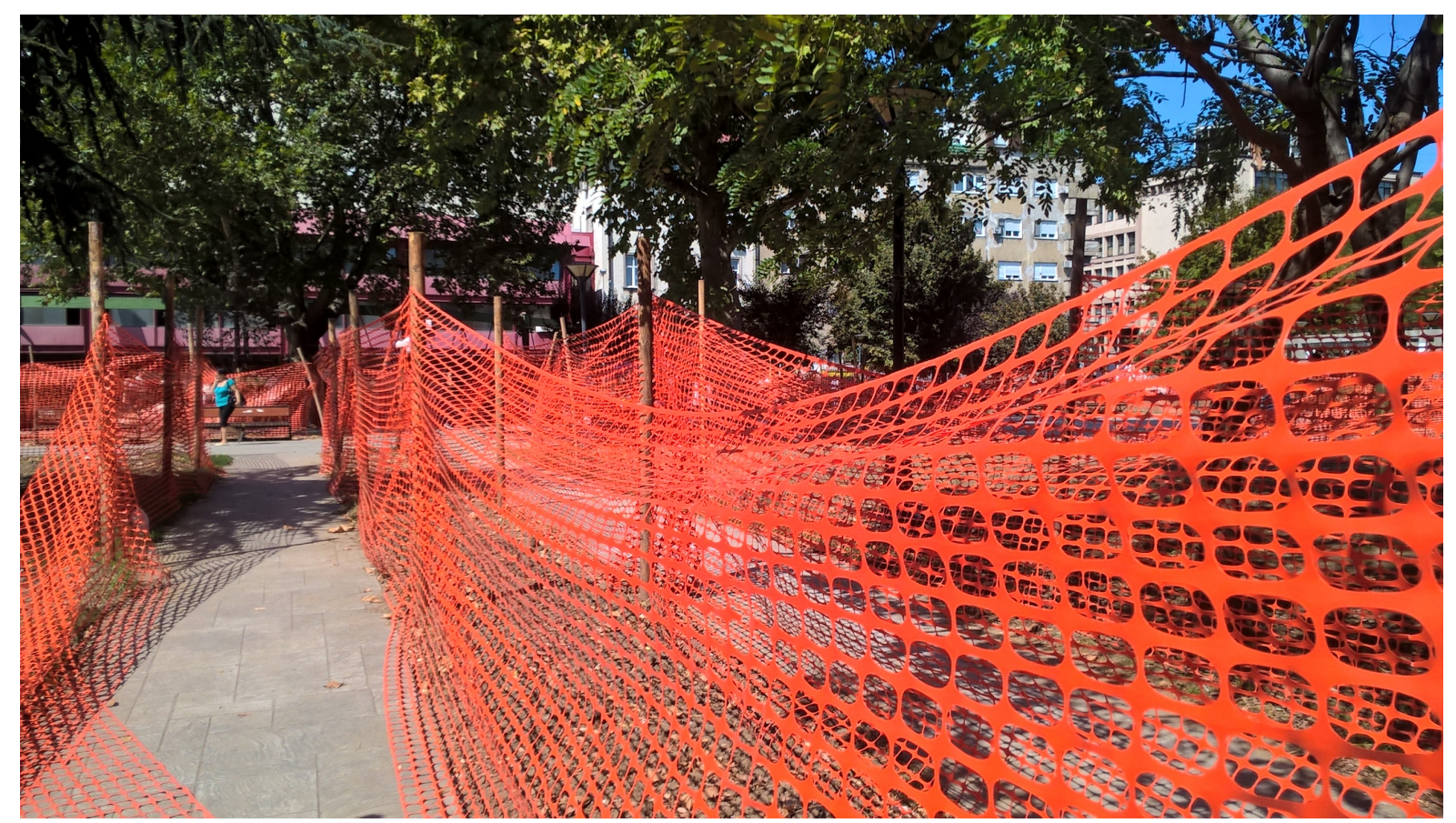

Photo 1: Orange fence preventing the use of the park. August 2016

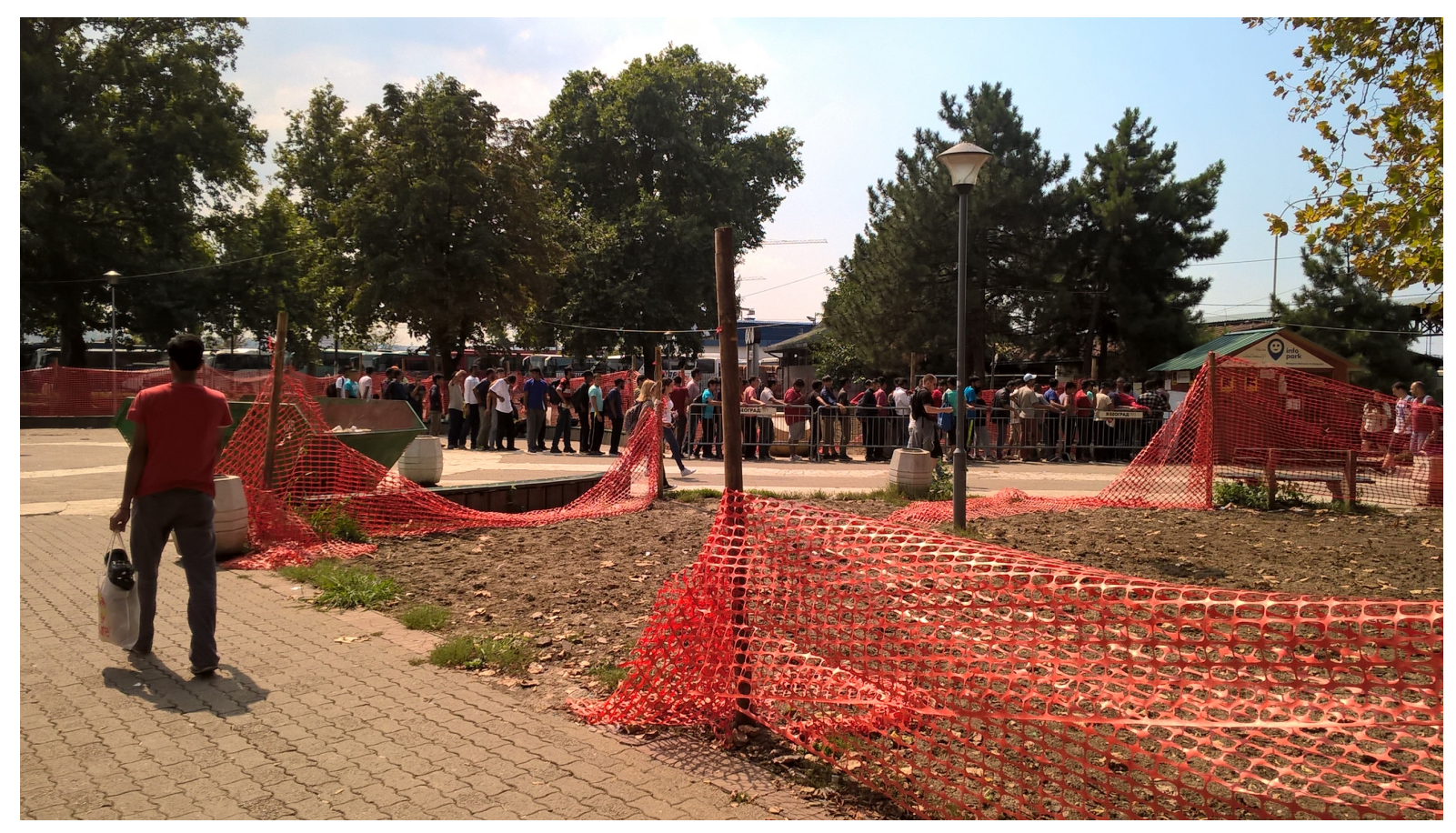

Photo 2: Food queues for the Refugee Aid Serbia meals. August 2016.

Despite the fence, activists continued providing aid and making contact with refugees; however, free access to the park became a major point of contention and a focus of their work, and included a 'Take back the park' festival, in which they, local residents and refugees played music, and 'decorated' the fence with artwork. Their attempts at using public spaces to make 
a broader point about refugees' right of presence reflects Creasap's (2012:184) point that it is through challenging 'who "belongs" in public (and in some cases, private), spaces', everyday practices become 'political work'.

One effect of the fence - a biopolitical technology - is that it made authorities' surveillance of the park easier. The fence created corridors which channelled pedestrians towards the centre then back out of the park, and ensured that those wishing to hang about in the park, could do so only in the park's central space - where Commissariat and police patrolled each day. Once the fences came down, the city put up new 'Keep off the grass' signs in English, Serbian, Farsi and Arabic: not only are such signs a rarity in Serbian parks, but the inclusion of English and Arabic makes it clear that this was an intervention aimed at refugees.

Perhaps the clearest example of biopolitical tools employed by the authorities was the eviction of activists from the park and the outright banning of aid provision outside of camps. According to a number of aid organisations, the government has always discouraged food and medical aid distribution in the parks as it was a 'pull factor' into the city, which pushed people away from camps. In October 2016, the Info Park NGO volunteers were evicted from the bus station park by city authorities. In November 2016, workers from two different agencies showed me a letter issued by the national government, directly forbidding the provision of aid 'in form of food, clothing, footwear, and supporting migrants to live outside of the transitreception centres. [...] ...especially on the territory of the City of Belgrade'. The letter - a biopolitical intervention into the lives of refugees - also adds that 'living in transit-reception migrant and asylum centres [refugee camps], where help is available (food, accommodation, clothes, medicines, psycho-social help and healthcare), is in the best interest of the migrants.' The letter, with its clear attempt at dispersing refugees from public spaces into reception centres, echoes the view that "the refugee camp is considered as the "proper" space for refugee populations, acting as a technology of spatial segregation that enables the containment of those displaced' (Darling 2016:3). However, the dispersal of aid provision from the park helped create what became known amongst refugees and aid workers as the 'Refugee District'19, one street away, where three key agencies including Info Park and MSF are now located. Not only are the aid organisations now generally left alone by the authorities - the Info Park NGO provides meals for newly arrived refugees, even though the new rules forbid this - but they also cooperate with the Commissariat for Refugees and various official services. For instance, Commissariat staff and a team of social workers from the Department for Social Welfare, are now embedded at one of the relocated volunteer-run aid centres. This suggests that presence of refugees in the city is not tolerated when it is public, visible or explicitly politicised but is tolerated and even supported away from the open spaces and commercial areas. Whilst the evictions from the park were meant to cut volunteer-run services for refugees, it is interesting to note that the evicted organisations such as Info Park now 
occupy larger premises and provide an even more comprehensive set of services to newly arrived refugees, including meals, computers, safe spaces and interpreters.

The 'subtle wielding of contemporary power' (Doty 2011) through fencing, surveillance or eviction, illustrates Williams' (2015:12) point that border and immigration reinforcement have undergone a 'spatial diffusion' in that they do not only take place at actual state borders but is diffused to other locations (Williams 2015:12; Darling 2016). Importantly, and in a slight departure from this view, the Belgrade case suggests that at city level at least, states do not enforce borders only by treating refugees and migrants as subjects of migration law. What is especially interesting - and what brings us to the Waterfront link - is that authorities were active in displacing and removing refugees from the park and other spaces related to the Waterfront development, but seemed to tolerate their presence in places that had no relationship to the new project, or were physically concealed from it (c.f. Merry 2001).

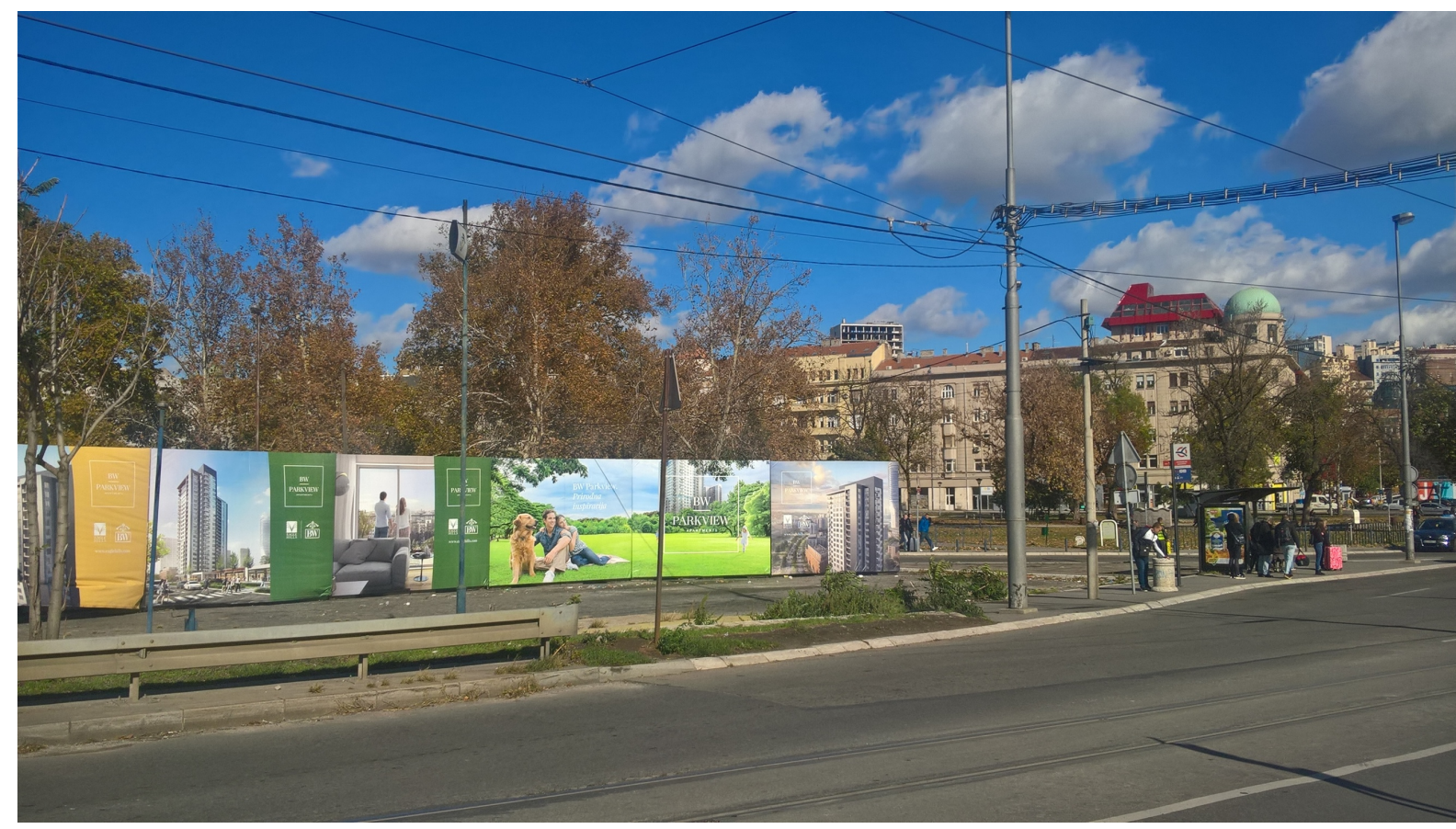

Photo 3: The park, now vacated by aid groups and most refugees, advertising Waterfront 'Park View' Apartments. October 2017.

\section{No Border Squat / 'The Gallery Promenade'}

After being pushed out of the parks the refugees refusing accommodation in official camps, found themselves in two separate, derelict sites nearby. Both became informal settlements; however, both also happened to be on land acquired for the Waterfront project. Whilst the two refugee squats have much more of an explicit link to the Waterfront development, it is mainly because of the biopolitical regulation of the parks that they found themselves using these sites in the first place. In 2015, as aid became more difficult to administer in the parks, a popular 
local club called 'Mixer House' stepped in to help by allowing their beer garden and concert venue called 'Miksaliste', to be used as an aid delivery point. Mixer House is located in Savamala, discussed above, on a street mostly incorporated into the Waterfront development.

The aid centre that came to be known as 'Miksaliste' was a small, open-air yard with volunteers (both local and European) providing food, water, clothing and footwear to several hundred refugees a day at the peak of the crisis. By autumn 2015, some of the businesses from the street and nearby had been moved and demolition of parts of the area had begun, in readiness for construction of Waterfront, whose billboards and advertising dominated the entire area.

Discussing cities as key sites of political action and revolt, Harvey (2012:118) notes that 'political protests frequently gauge their effectiveness in terms of their ability to disrupt urban economies.' The aid centre captures this dynamic as it disrupts the neoliberal order. In capitalist terms of the Waterfront project, the aid centre sat on a very expensive piece of real estate. When the bulldozing of the street began, this aid site literally stood in the way of the planned building works. It was also a site occupied by people who have no 'value' in a capitalist sense - the refugees and volunteers. The site thus 'devalues' the street and the Waterfront development, whilst showing the potential to 'build a political city out of the debilitating processes of neoliberal urbanization, and thereby reclaim the city for anti-capitalist struggle' (Harvey 0212:150).

Next door to the improvised aid centre, activists arriving from Greece occupied a vacant building, fixed it up with refugees and created the so called 'No Border Squat'. The building, a former bar, was also on a part of the street earmarked for demolition and the Waterfront development. Squatting, as Creasap (2012:185) highlights, is one form of place-based politics that has a special resonance in European left-wing movements, particularly as it is often associated with challenging corporatization or housing inequalities (Creasap 2012:185). It has practical aim, such as providing accommodation for the homeless (Creasp 2012), but, as Chatterton points out, it also seeks to create space for "the less "desirable" denizens of urban life', particularly those that 'do not have consumerism as their main reason for participation in the city' (Chatterton 2002:2). Locally, the squatter movement is under-developed as compared to its counterparts in the rest of Europe, and the labelling of the new refugee house as a 'squat' (using the English word) came primarily from European activists volunteering in Serbia.

The squat was basic, and had no furniture ${ }^{20}$. There was enough space for around fifty people but the numbers staying in the squat depended on the weather; one activist estimates that eighty people sheltered in the squat one rainy night. Mirroring the horizontal organisation of many squats globally, the residents and activists set up house rules: no alcohol, no open fires, no stealing) during an assembly. One activist I spoke to said they saw this as the beginning of a community, and refugees living there started to refer to the squat as their home. 
Only a month after it started operating, on 24 April 2016 (incidentally, parliamentary election night) the squat was bulldozed together with 12 other buildings on this block (including Miksaliste Aid Centre, discussed above), allegedly by local authorities - though, the exact circumstances and actors involved are still unclear (see Krik 2018). Occupants of the aid centre, Refugee Aid Serbia, received an eviction notice and were given only forty-eight hours to comply. Despite Waterfront signage and site plans popping up on the street soon after the demolitions, and despite Belgrade City Mayor Sinisa Mali making the link between the demolitions and Waterfront explicit - it is still unknown who actually hired the demolition crew, gave the order, and what the name of the demolition company was (Krik 2018), resonating with much of the theoretical literature on post-socialist clientelism, deregulation and 'wild capitalism' (Upchurch and Marinkovic 2011).

The squat activists and occupants decided not to fight the eviction since, 'a squat is the community, and this was just a building ${ }^{21}$. On demolition day, most refugees dispersed before the police arrived, but around seven remained, and were persuaded (or rather, threatened with jail if they failed to comply, according to activists present) by the police to register and to accept accommodation at a refugee camp ${ }^{22}$. At the time, one activist notes, 'we didn't know the scale of the [Waterfront] project, but we felt it ${ }^{23}$.

Whilst the demolitions were not specifically targeted at refugees, they had an immediate biopolitical effect on refugees passing through Belgrade. The systematic, if insidious and bureaucratic, displacement of refugees and aid providers from key spaces in the city, meant that as each phase of Waterfront construction began, refugees became less visible, either because they finally accepted places in camps, or because they had to keep moving from building to building in order to find accommodation.

Today, the former site of the aid distribution centre is a tidy, white-washed square and 'Gallery Promenade' stretching onto a riverside walkway built by the Waterfront developers. It is a space which 'creates expectations of behaviour and a system that is 'not targeted at reforming the individual' but rather on 'inducing cooperation with populations without individualising the object of regulation' (Merry 2001:20). Despite a large area around the former aid site and newly build Waterfront 'promenade' being made available for public use, in reality, refugee populations and solidarity activists do not enter nor use this space as they have been subtly conducted away from it. The promenade is busy, exposed and on a river bank, which makes it a long and narrow space unsuitable for any kind of aid delivery, concealed activities or congregation. The demolished aid centre (now known as Refugee Aid Serbia Miksaliste) has relocated to a vacant property of a bankrupt state-owned construction company, in the 'Refugee District', about five minutes' walk from the old site and on a street running alongside the park (incidentally, the new building is owned by the same state-owned company operates the Refugee Reception Centre Krnjaca, on the outskirs of Belgrade). 
According to a volunteer working there, officials from the Commissariat for Refugees helped Refugee Aid Serbia obtain tenancy of the new site, highlighting the messiness of informal aid and their relationships to state authorities. Likewise, this suggests yet again that presence of refugees is tolerated in specific concealed and contained areas, away from commercial sites.

Photo 4: Demolished aid centre and the start of construction of Waterfront's 'Gallery Promenade', August 2016.

\section{'The Barracks'/'BW Residence’}

The displacement of refugees from parks and demolition of the Savamala area led to the development of a second squat site on a derelict yard behind the train station - land also acquired for the Waterfront development. The yard was large and consisted of around a dozen barracks formerly used by railway workers and other residents, derelict warehouses and former cargo buildings, all vacated ahead of Waterfront construction. The site was empty of residents when it was 'discovered' and squatted by refugees around spring or summer of $2016^{24}$ - the exact details are unknown.

Aid workers estimated that several hundred people were living on this site (other activists suggest higher figures) - mainly men, though other local activists note seeing teenagers and some children ${ }^{25}$. There was no electricity on the site, no running water apart from a single tap, no facilities and no rubbish disposal. Some barracks had no windows, or had holes in the roof.

Unlike the parks across the road, the barracks were, at first, largely left alone by police. The Commissariat officials carried out daily patrols of the site to try and convince people to move to camps, but according to activists working at the barracks, the patrols appeared to be a formality and the staff rarely engaged with the refugees and appeared largely disinterested. There were no reports of arrests or altercations with the police until the demolition of the barracks, which suggests that the local authorities either tolerated the presence of refugees in the derelict site because they were 'concealed' (Merry 2001). Refugees squatted the site for around six months before they were evicted, and almost immediately upon their eviction, the barracks were demolished and construction of the 'BW Residence' part of the Waterfront project began. On eviction day, refugees were encouraged to register for camps, and transport was provided. Subsequently, the Obrenovac Reception Centre near Belgrade was opened mainly with the aim of accommodating the squatters, many of whom are still residing in the centre at the time of writing ${ }^{26}$.

The situation recalls again Merry's (2001) point that spatial governmentality is temporal, with specific populations being tolerated only on specific sites and at specific times, but not others. This illustrates the broader discussions of how urban space is managed such that the 
'undesirable' people are conducted away from public spaces, and into the marginal, precarious sites that are perhaps seen as 'suitable' for this population (Bulley 2016; Mitchell 1997).

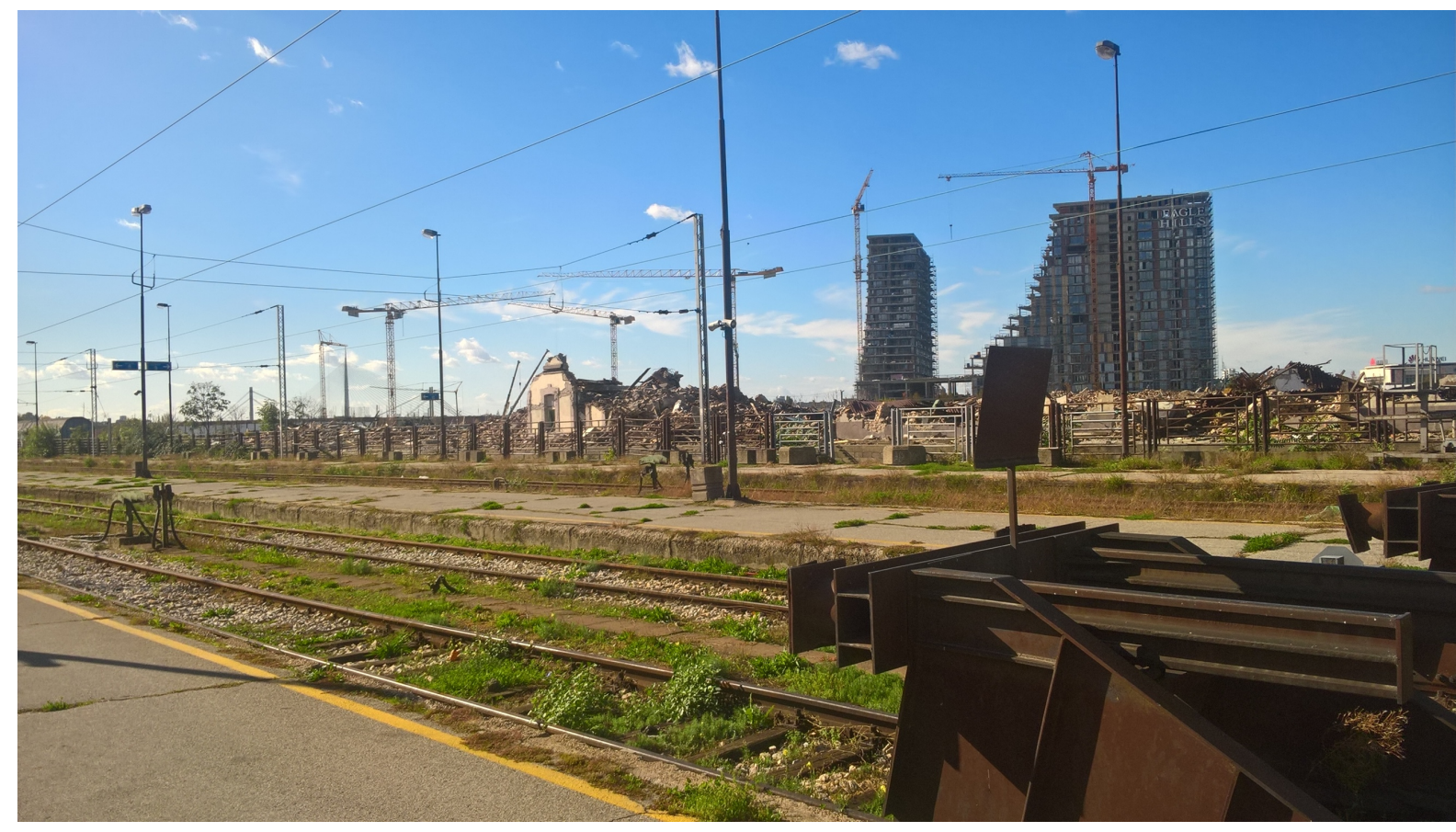

Photo 4: Belgrade Waterfront 'BW Residences' viewed from the train station. Rubble in front of the Waterfront building is from the demolished Barracks squat. October 2018.

Refugees are still arriving into Belgrade, and according to aid workers, many still sleep in parks or in the new Refugee Aid Miksaliste building whilst waiting for smugglers. New squats are constantly cropping up: one in a vacant and derelict building in the 'Refugee District' and one in a former department store (now vacated; and also on Waterfront land, according to the developers' maps). Others crop up in disused garages, and frequently, a smuggler will charge refugees' 'rent' (Augustova n.d.). This practice attests to the messiness of informal spaces and squats, which should not solely be seen in terms of 'resistance' to border regimes and neoliberalism. Aid workers have largely stopped delivering aid to the refugee population living in these informal spaces because they have become difficult to reach and find, and according to one interviewee, are increasingly wanting to stay invisible ${ }^{27}$.

\section{Conclusion}

This paper examined the spatial and urban politics of the refugee crisis by looking at the ways in which biopolitical and the logic of capitalism intersect in what might be labelled the migration-neoliberalism nexus. Specifically, the paper examined the effects this nexus has on refugee lives and their ability to use city spaces, create networks and obtain aid. The paper showed that states can appear to be supportive of refugees (not being constantly or explicitly 
xenophobic for instance, or by organising care in refugee camps) whilst at the same time deploying banal or everyday practices aimed at displacing refugees from public and commercial sites, and towards camps - or at least, out of public/investor view.

Biopolitical power of the state towards refugees is diffused to a vast network of actors who do the work of the state - 'anonymous' demolition companies that bulldoze the squat; the relatively anonymous investors pushing for a return on their investment and for their project to proceed and so on. This allows the state to govern at a distance (Barry et al 1996), disassociating themselves also from the worsening conditions for refugees outside of the camp system. The culmination of different biopolitical practices - the fence, patrols, surveillance of public places, and demolition of dwellings and support structures to make way for the Waterfront development, was ultimately successful in disrupting refugee-activist communities and conducting them away from centrally located spaces, yet, the state itself was rarely visible and present.

However, the paper also identified that there is a crucial difference between how refugees in urban centres are treated by local authorities, in comparison to other marginalised populations who are also pushed out of commercial and high value spaces. That difference hinges on the existence of the camp system, towards which refugees are constantly pushed. The presence of EU donor capital incentivises transit states such as Serbia to persist with policies which conduct all refugees into official camps. Refugee camps may be peripheral to cities in the sense that they are not geographically close, but the biopolitical rationalities that refugees in city centres are subjected to are shaped heavily by the camp system. Rather than seeing the camp and the city as dichotomous, it is more productive to think of them as related: local authorities are able to simultaneously push refugees out of commercial centres whilst drawing on the notion of a camp as a 'legitimate' space for refugee populations. Thus, by deploying the interventionist narrative that camps are 'the best' spaces for refugees, authorities are able to avoid charges of neglect and abandonment of this population, whilst evicting them from derelict spaces earmarked for development.

Many of the sites described in this paper have now been demolished or evicted. What the Belgrade case has shown is that refugees - in addition to learning to navigate international borders and evade capture and surveillance - also have to learn to navigate cities in similar ways. Once in the city, they have to learn to manage asylum systems, but also have to become aware of local politics and land disputes, which have a direct effect on their movements across urban spaces.

\section{References}

Afouxenidis, A., Petrou, M., Kandylis, G., Tramountanis, A., and D. Giannaki (2017) Dealing 
with a humanitarian crisis: refugees on the Eastern EU border of the Island of Lesvos Journal of Applied Security Research, 12-1, 7-39, DOI: 10.1080/19361610.2017.1228023

Augustova, K., n.d. Disorder at the EU Border: Migrant Men and Experiences of Illegality unpublished PhD Research, Aston University, Birmingham.

Ataç, I. (2016) 'Refugee Protest Camp Vienna': Making Citizens Through Locations of the Protest Movement Citizenship Studies 20 (5): 629-46. doi:10.1080/13621025.2016.1 82676 .

Barry, A., Osborne, T. and N. Rose eds. (1996) Foucault and political reason: liberalis/m, neoliberalism and rationalities of government Chicago: University of Chicago Press

Bauder, H. (2016) Possibilities of urban belonging Antipode 48(2): 252-271 DOI: 10.1111/anti. 12174

Beznec, B., Speer, M. and M. Stojic-Mitrovic (2016), Governing the Balkan Route: Macedonia, Serbia and the European Border Regime Rosa Luxembourg Stiftung Research Papers Southeast Europe No. 5. Belgrade: Rosa Luxembourg Stiftung.

Bulley, D. (2016) Occupy differently: space, community and urban counter-conduct' 1-21. Global Society doi:10.1080/13600826.2015.1133567.

Brenner, N., \& Theodore, N., (2002) Cities and the geographies of 'Actually existing neoliberalism' Antipode 34(3), 349e379.

Chatterton, P. (2002) 'Squatting is still legal, necessary and free': a brief intervention in the corporate city." Antipode 34 (1): 1-7. doi:10.1111/1467-8330.00223.

Creasap, K. (2012) Social movement scenes: place-based politics and everyday resistance Sociology Compass 6 (2): 182-91. doi:10.1111/j.1751-9020.2011.00441.x.

Cvetinovic, M, Maricic, T. and J. Bolay (2016) Participatory urban transformations in Savamala, Belgrade - capacities and limitations Spatium 36: 15-23 DOI: 10.2298/SPAT1636015C

Darling, J. (2016) Forced migration and the city: irregularity, informality, and the politics of presence' Progress in Human Geography Februar 1-21. doi:10.1177/0309132516629004.

Darieva, T. and Kaschuba, W. (2012) Sights and Signs of Postsocialist Urbanism in Eurasia: An Introduction in Darieva, T., Kaschuba, W. and M. Krebs eds. Urban Spaces after Socialism: Ethnographies of Public Places in Eurasian Cities Chicago:University of Chicago Press pp.

Davis, M., (1990) City of Quartz: Excavating the Future in Los Angeles London: Verso

Davies, T., Isakjee, A. and S. Dhesi (2017) Violent inaction: the necropolitical experience of refugees in Europe." Antipode 25 (3): 336-22. doi:10.1111/anti.12325.

Davies, T. and A. Isakjee (2015) Geography, migration and abandonment in the Calais Refugee Camp." Political Geography 49: 93-95. doi:10.1016/j.polgeo.2015.08.003

Depraetere, A. and S. Oosterlynck, (2017) 'I finally found my place': a political ethnography of the Maximiliaan refugee camp in Brussels Citizenship Studies 21(6): 693-709. DOI: $1080 / 13621025.2017 .1341653$ 
Doty, R. L. (2011) Bare life: border-crossing, deaths and spaces of moral alibi Environment and Planning D: Society and Space 29 (4): 599-612. doi:10.1068/d3110.

Eror, A. (2015) Belgrade's 'top-down' gentrification is far worse than any cereal cafe The Guardian https://www.theguardian.com/cities/2015/dec/10/belgrade-top-downgentrification-worse-than-cereal-cafe Accessed 9 April 2018

Fábos, A. H. (2007) Editorial: 'Urban Refugees: Introduction' (with Gaim Kibreab) In Fábos, A. and Kibreab, G. (Eds) Refugees in Urban Settings of the Global South. Special Issue of Refuge: Canada's Periodical on Refugees 24(1) 1-19

Ferguson, J. and A. Gupta (2002) Spatializing states: toward an ethnography of neoliberal governmentality American Ethnologist 29 (4): 981-1002

Fraser, N., (1990) Rethinking the public sphere: a contribution to actually existing democracy Social Text 25/26: 56-79

Foucault, M. (2000) Power: Essential Works of Foucault 1954-1984 Volume 2 London: Penguin

Foucault, M., (1997) Society Must be Defended: Lectures at the Collège de France 1975-1976 New York: Picador

Green, L. (2011) The Nobodies: neoliberalism, violence and migration Medical Anthropology 30(4): 366-385 DOI: 10.1080/01459740.2011.576726

Greenberg, J. and I. Spasic (2017) Beyond East and West: Solidarity politics and the absent/present state in the Balkans Slavic Review 76 (2)315-326, DOI: 10.1017/sIr.2017.80

Grubbauer, M. and N. Camprag (2018) Urban megaprojects, nation-state politics and regulatory capitalism in Central and Eastern Europe: the Belgrade Waterfront Project Urban Studies, Online First, 1-23, DOI:10.1177/0042098018757663

Halbert, L., and H. Rouanet (2013) Filtering risk away: global finance capital, transpolar territorial networks and the unmaking of city-regions: an analysis of business property development in Bangalore, India Regional Studies 48 (3): 371-484

Harloe, M., (1996) 'Cities in Transition' in Cities After Socialism: Urban and Regional Change and Conflict in Post-Socialist Societies, eds. G. Andrusz, M. Harloe and I. Szelenyi. WileyBlackwell.

Harvey, D., (2012) Rebel cities: from the right to the city to the urban revolution London: Verso

Hirt, S. (2013) Whatever happened to the (post)socialist city? Cities 32: 29-38

Hirt, S. (2008) Landscapes of postmodernity: changes in the built fabric of Belgrade and Sofia since the end of socialism Urban Geography 29 (8): 785-810, DOI: 10.2747/02723638.29.8.785

Jansen, S. (2001) The streets of Beograd. Urban space and protest identities in Serbia Political Geography 20 (1) 35-66 DOI https://doi.org/10.1016/S0962-6298(00)00052-4

Jessop, B. (2002) Liberalism, neoliberalism and urban governance: a state-theoretical perspective' Antipode 34 (3) 452-472 
Johnson, H. L. (2016) These fine lines: locating noncitizenship in political protest in Europe." Citizenship Studies 19 (8): 951-65. doi:10.1080/13621025.2015.1110287.

Johnson, L. (2015) Material interventions on the US-Mexico border: investigating a sited politics of migrant solidarity Antipode 47 (5): 1243-60. doi:10.1111/anti.12151.

Johnson, K. (2007) Opening the Floodgates: Why America Needs to Rethink its Border and Immigration Laws New York: New York University Press

Kraftl, P. (2014) Liveability and urban architectures: mol(ecul)ar biopower and the 'becoming lively' of Sustainable Communities." Environment and Planning D: Society and Space 32 (2): 274-92. doi:10.1068/d21012.

Krik (2018) Savamala https://www.krik.rs/tag/rusenje-savamala/ accessed 2 May 2018

Lamb, I. (2016) The Gates of Greece: Refugees and Policy Choices Mediterranean Quarterly 27 (2):67-88 https://doi.org/10.1215/10474552-3618072

Maestri, G. and S. M. Hughes (2017) Contested spaces of citizenship: camps, borders and urban encounters Citizenship Studies 21 (6): 625-639 DOI: $10.1080 / 13621025.2017 .1341657$

Mihaliovic, B., (2014) 'Vucic’s Belgrade: a city walled in' Kamenzid No. 5, 32-43

Mountz, A. (2011). Where asylum-seekers wait: feminist counter-topographies of sites between states. Gender, Place \& Culture 18, pp. 381-399

Mudu, P., and Chattopadhyay, S. eds. (2017) Migration, Squatting and Radical Autonomy London: Routledge

Naskovic, D., 2017, Vucic i Kurc: Srbija ne primenjuje silu prema izbeglicama N1 http://rs.n1 info.com/a227895/Vesti/Vesti/Vucic-i-Kurc-Srbija-ne-primenjuje-silu-premaizbeglicama.html Accessed 27 August 2018

Nordling, V., M. Sager \& E. Soderman (2017) From citizenship to mobile commons: reflections on the local struggles of undocumented migrants in the city of Malmo, Sweden Citizenship Studies 21 (6):710-726, DOI: 10.1080/13621025.2017.1341660

Nyers, P. (2003) Abject cosmopolitanism: the politics of protection in the anti-deportation movement, Third World Quarterly, 24(6), pp. 1069-1093.

Nyers, P. (2010) No one is illegal between city and nation, Studies in Social Justice 4 (2) 127143

McNevin, A. (2006) Political belonging in a neoliberal era: the struggle of the Sans-Papiers." Citizenship Studies 10 (2): 135-51. doi:10.1080/13621020600633051.

Matkovic, A. and M. Ivkovic (2018) Neoliberal insturmetalism and the fights against it: the 'We Won't let Belgrade D(r)own' Movement East European Politics Online First

Merry, S. E. (2001) Spatial governmentality and the new urban social order: controlling gender violence through law American Anthropologist 103 (1): 16-29

Mezzarda, S. and B. Nielson, (2012) Between inclusion and exclusion: on the topology of global space and borders Theory, Culture and Society 29(4/5) 58-75 
Mitchell, D., (1995) The end of public space? People's Park, definitions of the public, and democracy' Annals of the Association of American Geographers 85 (1) 108-133

Peck, J., Theodore, N. and N. Brenner (2011) Neoliberal urbanism redux? International Journal of Regional and Urban Research 37(3) 1091-1099 https://doi.org/10.1111/14682427.12066

Peck, J., Theodore, N., and Brenner, N. (2009) 'Neoliberal Urbanism: Models, Moments, Mutations,' SAIS Review XXIX (1) 49-66

Petrovic, M. and Timotijevic M. (2013) Homelessness and Housing Exclusion in Serbia, European Journal of Homelessness 7(2) pp.267-286

Pink, S., (2008) 'Rethinking contemporary activism: from community to emplaced solidarity.' Ethnos 73(2), 163-188

Pomorska, K. and G. Noutcheva, (2017) Europe as a regional actor: waning influence in an unstable and authoritarian neighbourhood' Journal of Common Market Studies Annual Review 55: 165-176

Pugh, M. (2005) Transformation in the Political Economy of Bosnia Since Dayton International Peacekeeping 12 (3): 448-62

Routledge, P. (2009) Transnational resistance: global justice networks and spaces of convergence Geography Compass 3 (5): 1881-1901. doi:10.1111/j.17498198.2009.00261.x.

Rygiel, K. (2011) Bordering solidarities: migrant activism and the politics of movement and camps at Calais Citizenship Studies 15 (1): 1-19. doi:10.1080/13621025.2011.534911

Sanyal, R. (2012) Refugees and the city: an urban discussion Geography Compass 6 (11): 633-644

Sarajlija, M., Jugovic, A., Zivaljevic, D., Merdovic, B. and A. Sarajlija (2014) Assessment of health status and quality of life of homeless persons in Belgrade, Serbia Vojnosanitetski Pregled 71(2): 167-174

Sparke, M. (2006) A Neoliberal nexus: Economy, security and the biopolitics of citizenship at the border, Political Geography 25, 151-180

Springer, S. (2010) Neoliberalism and geography: expansions, variegations, formations Geography compass 4 (8), 10-25-1038 DOI: 10.1111/j.1749-8198.2010.00358.x

Squire, V. (2014) Desert 'Trash': Posthumanism, Border Struggles, and Humanitarian Politics Political Geography 39: 11-21. doi:10.1016/j.polgeo.2013.12.003.

Sykora, L, and S Bouzarovski. (2011) 'Multiple Transformations: Conceptualising the PostCommunist Urban Transition.' Urban Studies 49 (1): 43-60. doi:10.1177/0042098010397402.

Topak, A. E. (2014) The Biopolitical border in practice: surveillance and death at the GreeceTurkey borderzones Environment and Planning D: Society and Space 32 (5): 815-33. doi: 10.1068/d13031p.

Tsianos, V. and S. Karakayali (2010) Transnational migration and the emergence of the 
European border regime: an ethnographic analysis European Journal of Social Theory 13(3)373-387

Tsavdaroglou, C. (2018) The Newcomers' rights to the common space: the case of Athens during the refugee crisis ACME: An International Journal of Critical Geography Preprint, 126

United Nations High Commissioner for Refugees (2017a) Desperate refugees and migrants in Serbia face freezing temperatures http://www.unhcr.org/uk/news/latest/2017/1/5888861b4/desperate-refugees-migrantsserbia-face-freezing-temperatures.html Accessed 3 March 2017

United Nations High Commissioner for Refugees (2017b) Europe refugee situation: Serbia in numbers http://reliefweb.int/sites/reliefweb.int/files/resources/Serbia\%202016\%20UNHCR.pdf accessed 2 February 2017

Upchurch, M. and D. Marinkovic (2011) 'Wild Capitalism, privatisation and employment relations in Serbia' Employee Relations 33 (4): 316-333

Vojovic, S. and M. Petrovic (2007) Belgrade's post-socialist urban revolution: reflections by the actors in the development process, in ed. K. Stanilov The Post-Socialist City: urban transformations in Central and Eastern Europe after socialism New York: Springer pp. 361-383

Williams, J. M. (2015) From humanitarian exceptionalism to contingent care: care and enforcement at the humanitarian border Political Geography 47: 11-20. doi:10.1016/j.polgeo.2015.01.001.

\section{Endnotes}

\footnotetext{
${ }^{1}$ European Civil Protection and Humanitarian Operations, https://ec.europa.eu/echo/where/europe-and-central-asia/serbia_en Accessed 20 August 2018

${ }^{2}$ In July 2017 and July 2018, I also carried out field research in Athens, and some of the information from those trips is referenced in this paper.

${ }^{3}$ Eagle Hills, https://www.eaglehills.com accessed 10 April 2018

${ }^{4}$ Interview with Commissariat for Refugees staff members. Belgrade, June 2018.

${ }^{5}$ Interview with official from the City of Athens Coordination Centre for Migrant and Refugee Issues, July 2018.

${ }^{6}$ Author interview with aid worker, Belgrade, October 2017

${ }^{7}$ Interview with local NGO workers, Belgrade, June 2018.

${ }^{8}$ Eagle Hills, https://www.belgradewaterfront.com/sr/projekti/bw-parkview/ accessed 2 May 2018

${ }^{9}$ Interviews with four Belgrade-based volunteers; November 2015; June 2016; August 2016 and June 2018.

${ }^{10}$ Interview with Krnjaca Reception Centre staff member; interview with City of Belgrade social worker, June 2018.

${ }^{11}$ Interview with Krnjaca Reception Centre staff member. Belgrade, June 2018.

${ }^{12}$ Interview with Commissariat for Refugees staff member; Interview with Krnjaca Reception Centre staff member. Belgrade, June 2018.

${ }^{13}$ Interview with Krnjaca Reception Centre staff member, June 2018.
} 
${ }^{14}$ Commissariat for Refugees http://www.kirs.gov.rs/articles/centers.php?lang=ENG accessed 23 August 2018

${ }^{15}$ Interview with local NGO worker, Belgrade, November 2017.

${ }^{16}$ Interview with Belgrade-based aid worker, Belgrade November 2017.

${ }^{17}$ Interview with a Belgrade-based activist, August 2016

${ }^{18}$ Interview with a Belgrade based activist, August 2016

${ }^{19}$ The term 'Refugee District' was said to be in use by refugees themselves, interview, aid worker, Belgrade, October 2017.

${ }^{20}$ Interview with activist, Belgrade, August 2016.

${ }^{21}$ Interview with activist, Belgrade, August 2016

22 Interview with activist, Belgrade, August 2016

${ }^{23}$ Interview with activist, Belgrade, August 2016

${ }^{24}$ Interviews with activists and aid workers, Belgrade, August 2016.

${ }^{25}$ Interviews with aid workers and activists, Belgrade, August 2016.

${ }^{26}$ Interviews with aid workers, October 2017 and June 2018.

${ }^{27}$ Interview, aid worker, Belgrade October 2017. 